Acta Crystallographica Section C

\section{Crystal Structure}

Communications

ISSN 0108-2701

\section{A liquid crystal derived from ruthenium(II,III) and a long-chain carboxylate}

\author{
Andrés Zelcer, ${ }^{\text {a }}$ Zulema D. Chaia, ${ }^{\text {a* }}$ Fabio D. Cukiernik, ${ }^{\text {a,b }}$ \\ Eduardo E. Castellano ${ }^{c}$ and Oscar E. Piro ${ }^{d}$
}

aINQUIMAE, Departamento de Química Inorgánica, Analítica y Química Física, Facultad de Ciencias Exactas y Naturales, Universidad de Buenos Aires, Ciudad Universitaria, Pabellón II, 1428 Buenos Aires, Argentina, ${ }^{\mathbf{b}}$ Instituto de Ciencias, Universidad Nacional de General Sarmiento, Roca 850, 1663 San Miguel, Buenos Aires, Argentina, 'Instituto de Fisica de São Carlos, Universidad de São Paulo, CP 369, 13560 São Carlos (SP), Brazil, and departamento de Física, Facultad de Ciencias Exactas, Universidad Nacional de La Plata and IFLP (CONICET), CC 67, 1900 La Plata, Argentina

Correspondence e-mail: zchaia@qi.fcen.uba.ar

Received 21 September 2001

Accepted 17 December 2001

Online 13 February 2002

The title compound, catena-poly[[tetrakis $\left(\mu\right.$-decanoato- $\left.\kappa^{2} O: O^{\prime}\right)$ diruthenium(II,III) $(R u-R u)]-\mu$-octanesulfonato- $\left.\kappa^{2} O: O^{\prime}\right]$, $\left[\mathrm{Ru}_{2}\left(\mathrm{C}_{10} \mathrm{H}_{19} \mathrm{O}_{2}\right)_{4}\left(\mathrm{C}_{8} \mathrm{H}_{17} \mathrm{O}_{3} \mathrm{~S}\right)\right]$, is an octanesulfonate derivative of the mixed-valence complex diruthenium tetradecanoate. The equatorial carboxylate ligands are bidentate, bridging two $\mathrm{Ru}$ atoms to form a dinuclear structure. Each of the two independent dinuclear metal complexes in the asymmetric unit is located at an inversion centre. The octanesulfonate anion bridges the two dinuclear units through axial coordination. The alkyl chains of the carboxylate and sulfonate ligands are arranged in a parallel manner. The global structure can be seen as infinite chains of polar moieties separated by a double layer of non-polar alkyl groups, without interdigitation of the alkyl chains.

\section{Comment}

Mixed-valence diruthenium(II,III) tetracarboxylates, [ $\mathrm{Ru}_{2^{-}}$ $\left.\left(\mathrm{O}_{2} \mathrm{CR}\right)_{4} \mathrm{X}\right]\left(\mathrm{X}^{-}\right.$is an anion), have been extensively studied in recent years because they exhibit interesting electronic structures, spectroscopic features, magnetic behaviour and liquid crystalline (LC) properties (Aquino, 1998). In particular, LC phases (mesophases) have been obtained with longchain carboxylates, provided that an appropriate combination of the equatorial carboxylate $\left(\mathrm{RCO}_{2}{ }^{-}\right)$and axial anion $\left(X^{-}\right)$is used (Cukiernik, Ibn-Elhaj et al., 1998; Chaia et al., 1999; Caplan et al., 1999). For example, aliphatic equatorial carboxylates combined with long-chain axial anions, such as dodecylsulfate or an aliphatic carboxylate, induce mesomorphic behaviour (Cukiernik, Ibn-Elhaj et al., 1998). In some of these cases, a model describing the structural changes taking place through the phase transition has been proposed.
As is usual in LC work, these models were based on the structural parameters of the LC phase (obtained from powder $\mathrm{X}$-ray diffraction experiments), on information provided by local spectroscopic probes and on the crystalline structure of short-chain (non-mesogenic) analogues.

Of the more than 30 structures of mixed-valence diruthenium carboxylates that are known, the great majority deal with short-chain analogues (Bennett et al., 1969; Bino et al., 1979; Togano et al., 1980; Cotton et al., 1988; Barral et al., 1997). The longest chain $\left[\mathrm{Ru}_{2}\left(\mathrm{O}_{2} \mathrm{CR}\right)_{4} X\right]$ compound for which the molecular structure is known is the non-mesogenic pentanoate derivative $\left[\mathrm{Ru}_{2}\left\{\mathrm{O}_{2} \mathrm{C}\left(\mathrm{CH}_{2}\right)_{3} \mathrm{CH}_{3}\right\}_{4} \mathrm{Cl}\right]$ (Cukiernik, Luneau et al., 1998). We have now determined the structure of the title ruthenium decanoate derivative with octanesulfonate as the axial anion, $\left[\mathrm{Ru}_{2}\left\{\mathrm{O}_{2} \mathrm{C}\left(\mathrm{CH}_{2}\right)_{8} \mathrm{CH}_{3}\right\}_{4}\left\{\mathrm{O}_{3} \mathrm{~S}\left(\mathrm{CH}_{2}\right)_{7} \mathrm{CH}_{3}\right\}\right]$, (I). This compound is particularly interesting, as it undergoes a transition to a thermotropic hexagonal columnar LC phase at $458 \mathrm{~K}$. We are confident that the crystal structure information we report here will be useful when interpreting the structure of the mesophase of the whole $\left[\mathrm{Ru}_{2}\left\{\mathrm{O}_{2} \mathrm{C}\left(\mathrm{CH}_{2}\right)_{n}\right.\right.$ $\left.\left.\mathrm{CH}_{3}\right\}_{4}\left\{\mathrm{O}_{3} \mathrm{~S}\left(\mathrm{CH}_{2}\right)_{7} \mathrm{CH}_{3}\right\}\right]$ series of compounds, with $n=8-16$.

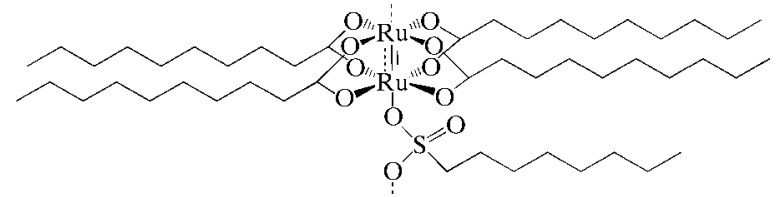

(I)

In compound (I), an $\left\{\mathrm{Ru}_{2}\right\}^{5+}$ metallic centre is bridged by four carboxylate equatorial ligands; the axial positions are occupied by the octanesulfonate anion. The unit cell contains two independent dinuclear complexes, each located at a crystallographic inversion centre. The $\mathrm{Ru}$ atoms are in an environment of approximately $C_{4 v}$ symmetry, while the dinuclear structure exhibits approximate $D_{4 h}$ symmetry.

The $\mathrm{Ru}-\mathrm{O}$ equatorial bond distances are in the range 2.019 (3)-2.034 (3) A. The average $\mathrm{O}-\mathrm{C}-\mathrm{O}$ bond angle of the carboxylate ligands is $123.1(3)^{\circ}$, and the $\mathrm{O}_{i}-\mathrm{Ru}_{j}-\mathrm{Ru}_{j}^{\prime}$ angles $(i=11,12,13,14,21,22,23$ or 24 , and $j=1$ or 2$)$ are nearly $90^{\circ}$. Thus, the pseudo-octahedral environment of the $\mathrm{Ru}$ atoms is not significantly distorted, indicating that the dinuclear structure is achieved with little stress around the metal centres.

The $\mathrm{Ru}-\mathrm{Ru}^{\prime}$ distance is 2.271 (3) $\AA$ (averaged for the two independent dinuclear units), a typical value for mixedvalence diruthenium carboxylates axially coordinated by $\mathrm{O}$ atoms (Aquino, 1998). Four alkyl chains from carboxylate ligands are oriented towards the periphery of the polar centre in a zigzag conformation; two are completely extended, while the others rotate around the $\beta$-C atom ( $\mathrm{C} 12$ and $\mathrm{C} 32)$ in order to align with the former chains. The alkyl chain of the sulfonate ligand also aligns in an extended conformation parallel to the carboxylic acid alkyl chains.

The alkylsulfonate moiety acts as a bidentate ligand bridging two independent dinuclear units (Fig. 1). The three $\mathrm{S}-\mathrm{O}$ distances are consistent with double bonds, although the $\mathrm{S}-$ 


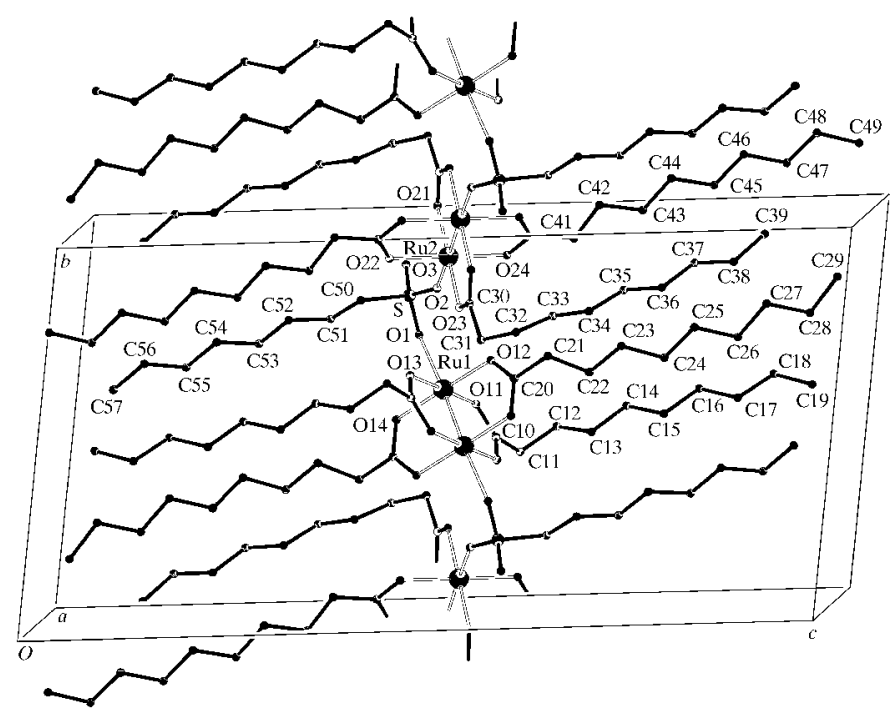

Figure 1

The crystal packing of (I) viewed down the $a$ axis, showing the non- $\mathrm{H}$ atom labelling. Only the most populated (61\% occupancy) of the two conformations of the $\mathrm{C} 1 n$ chain is shown for clarity.

$\mathrm{O} 3$ bond is significantly shorter than the other two. This can be ascribed to a slight softening of the $\mathrm{S}-\mathrm{O}$ bonds involved in coordination to the $\mathrm{Ru}$ centres $(\mathrm{S}-\mathrm{O} 1$ and $\mathrm{S}-\mathrm{O} 2)$, arising from $\pi$ back-donation.

Due to the bridging nature of the octanesulfonate axial anion, the bimetallic centres polymerize in an infinite chain nearly parallel to the $b$ axis. An intermolecular distance along the polymeric structure of 6.76 (1) $\AA$ can be calculated, being the distance between two neighbouring dinuclear centres. The corresponding $\mathrm{Ru}-\mathrm{Ru}$ axes are nearly perpendicular to each other $\left[91.94(4)^{\circ}\right]$. However, all the aliphatic chains (both carboxylic and sulfonic) of each such polymeric structure are parallel, without interdigitation.

In the global structure, polar chains composed of dinuclear centres and sulfonate axial ligands are separated by non-polar double layers of alkyl chains. An interlayer separation of 26.623 (3) $\AA$ can be inferred from the distance between adjacent $a b$ faces. There is no interdigitation between adjacent layers.

\section{Experimental}

$\left[\mathrm{Ru}_{2}\left\{\mathrm{O}_{2} \mathrm{C}\left(\mathrm{CH}_{2}\right)_{8} \mathrm{CH}_{3}\right\}_{4} \mathrm{Cl}\right]$ was synthesized following a method already reported for other homologues of this series (Cukiernik, IbnElhaj et al., 1998). Compound (I) was obtained by a metathesis reaction. A methanol suspension of $\left[\mathrm{Ag}\left\{\mathrm{O}_{3} \mathrm{~S}\left(\mathrm{CH}_{2}\right)_{7} \mathrm{CH}_{3}\right\}\right](150 \mathrm{mg})$ was added slowly to $\left[\mathrm{Ru}_{2}\left\{\mathrm{O}_{2} \mathrm{C}\left(\mathrm{CH}_{2}\right)_{8} \mathrm{CH}_{3}\right\}_{4} \mathrm{Cl}\right](418 \mathrm{mg})$ dissolved in methanol. The reaction was protected from light and refluxed for $3 \mathrm{~h}$ under nitrogen. The $\mathrm{AgCl}$ by-product was filtered off while still hot and the solvent was evaporated under vacuum. The pale-brown solid obtained was dissolved in $\mathrm{CH}_{2} \mathrm{Cl}_{2}$, the solution was filtered on a $0.2 \mu \mathrm{m}$ porous membrane and, after addition of heptane, the $\mathrm{CH}_{2} \mathrm{Cl}_{2}$ was evaporated under vacuum. After a couple of hours, a pale-brown solid was filtered off, and then washed by suspension in ethylic ether and distilled water. Brown crystals of (I) were obtained by slow evaporation of a methanolic solution. Characterization was performed by IR spectroscopy ( $\mathrm{KBr}$ pellets) on an FT-IR Nicolet 510P and by elemental analysis on a Carlo Erba EA1108 analyzer. IR spectroscopic analysis $\left(v, \mathrm{~cm}^{1-}\right): 1249(\mathrm{~m})\left(v_{\mathrm{S}-\mathrm{O}} \mathrm{SO}_{3}\right), 1115(\mathrm{~s})\left(v_{\mathrm{S}-\mathrm{O}}\right.$ $\left.\mathrm{SO}_{3}\right)$; analysis calculated for $\mathrm{C}_{48} \mathrm{H}_{93} \mathrm{O}_{11} \mathrm{Ru}_{2} \mathrm{~S}$ : C 53.36, S 2.97, $\mathrm{H} 8.68 \%$; found: $\mathrm{C} 53.50, \mathrm{~S} 2.26, \mathrm{H} 8.63 \%$; calculated for $\mathrm{C}_{40} \mathrm{H}_{76} \mathrm{ClO}_{8} \mathrm{Ru}_{2}$ : C 52.07, $\mathrm{H} 8.30 \%$; found: C 51.31, H 8.39\%.

\section{Crystal data}

$\begin{array}{ll}{\left[\mathrm{Ru}_{2}\left(\mathrm{C}_{10} \mathrm{H}_{19} \mathrm{O}_{2}\right)_{4}\left(\mathrm{C}_{8} \mathrm{H}_{17} \mathrm{O}_{3} \mathrm{~S}\right)\right]} & Z=2 \\ M_{r}=1080.43 & D_{x}=1.321 \mathrm{Mg} \mathrm{m}^{-3} \\ \text { Triclinic, } P \overline{1} & \text { Mo } K \alpha \text { radiation } \\ a=8.0020(1) \AA & \text { Cell parameters from } 8725 \\ b=13.3040(4) \AA & \quad \text { reflections } \\ c=26.7230(6) \AA & \theta=1.0-27.5^{\circ} \\ \alpha=83.427(2)^{\circ} & \mu=0.65 \mathrm{~mm}^{-1} \\ \beta=85.045(1)^{\circ} & T=120(2) \mathrm{K} \\ \gamma=74.051(1)^{\circ} & \text { Thin plate, red } \\ V=2712.9(1) \AA^{3} & 0.40 \times 0.18 \times 0.06 \mathrm{~mm}\end{array}$

Table 1

Selected geometric parameters $\left(\AA,^{\circ}\right)$.

\begin{tabular}{|c|c|c|c|}
\hline $\mathrm{Ru} 1-\mathrm{O} 12$ & $2.023(3)$ & $\mathrm{Ru} 2-\mathrm{O} 23$ & $2.035(3)$ \\
\hline $\mathrm{Ru} 1-\mathrm{O} 14$ & $2.028(3)$ & $\mathrm{Ru} 2-\mathrm{O} 22$ & $2.034(3)$ \\
\hline $\mathrm{Ru} 1-\mathrm{O} 13$ & $2.020(3)$ & $\mathrm{Ru} 2-\mathrm{O} 2$ & $2.233(3)$ \\
\hline $\mathrm{Ru} 1-\mathrm{O} 11$ & $2.029(3)$ & $\mathrm{Ru} 2-\mathrm{Ru} 2^{\mathrm{ii}}$ & $2.2732(6)$ \\
\hline $\mathrm{Ru} 1-\mathrm{O} 1$ & $2.228(3)$ & $\mathrm{O} 21-\mathrm{C} 30^{\mathrm{ii}}$ & $1.278(5)$ \\
\hline $\mathrm{Ru} 1-\mathrm{Ru} 1^{\mathrm{i}}$ & $2.2680(6)$ & $\mathrm{O} 22-\mathrm{C} 40^{\mathrm{ii}}$ & $1.275(5)$ \\
\hline $\mathrm{O} 11-\mathrm{C} 10$ & $1.284(5)$ & $\mathrm{O} 23-\mathrm{C} 30$ & $1.282(5)$ \\
\hline $\mathrm{C} 10-\mathrm{O} 13^{\mathrm{i}}$ & $1.265(5)$ & $\mathrm{C} 30-\mathrm{O} 21^{\mathrm{ii}}$ & $1.278(5)$ \\
\hline $\mathrm{C} 10-\mathrm{C} 11$ & $1.504(8)$ & $\mathrm{C} 30-\mathrm{C} 31$ & $1.491(6)$ \\
\hline $\mathrm{C} 10-\mathrm{C} 11^{\prime}$ & $1.505(9)$ & $\mathrm{C} 40-\mathrm{O} 22^{\mathrm{ii}}$ & $1.275(5)$ \\
\hline $\mathrm{O} 12-\mathrm{C} 20$ & $1.262(5)$ & $\mathrm{C} 40-\mathrm{C} 41$ & $1.486(5)$ \\
\hline $\mathrm{C} 20-\mathrm{O} 14^{\mathrm{i}}$ & $1.275(5)$ & $\mathrm{S}-\mathrm{O} 3$ & $1.430(4)$ \\
\hline $\mathrm{C} 20-\mathrm{C} 21$ & $1.502(5)$ & $\mathrm{S}-\mathrm{O} 1$ & $1.467(3)$ \\
\hline $\mathrm{O} 13-\mathrm{C} 10^{\mathrm{i}}$ & $1.265(5)$ & $\mathrm{S}-\mathrm{O} 2$ & $1.471(3)$ \\
\hline $\mathrm{O} 14-\mathrm{C} 20^{\mathrm{i}}$ & $1.275(5)$ & $\mathrm{S}-\mathrm{C} 50$ & $1.785(5)$ \\
\hline $\mathrm{Ru} 2-\mathrm{O} 24$ & $2.019(3)$ & $\mathrm{C} 50-\mathrm{C} 51$ & $1.507(6)$ \\
\hline $\mathrm{Ru} 2-\mathrm{O} 21$ & $2.021(3)$ & C51-C52 & $1.519(6)$ \\
\hline $\mathrm{O} 12-\mathrm{Ru} 1-\mathrm{O} 14$ & $178.8(1)$ & $\mathrm{O} 24-\mathrm{Ru} 2-\mathrm{O} 22$ & $178.6(1)$ \\
\hline $\mathrm{O} 12-\mathrm{Ru} 1-\mathrm{O} 13$ & $90.8(1)$ & $\mathrm{O} 21-\mathrm{Ru} 2-\mathrm{O} 22$ & $88.7(1)$ \\
\hline $\mathrm{O} 14-\mathrm{Ru} 1-\mathrm{O} 13$ & 89.9 (1) & $\mathrm{O} 23-\mathrm{Ru} 2-\mathrm{O} 22$ & $91.4(1)$ \\
\hline $\mathrm{O} 12-\mathrm{Ru} 1-\mathrm{O} 11$ & $89.8(1)$ & $\mathrm{O} 24-\mathrm{Ru} 2-\mathrm{O} 2$ & $89.3(1)$ \\
\hline $\mathrm{O} 14-\mathrm{Ru} 1-\mathrm{O} 11$ & $89.5(1)$ & $\mathrm{O} 21-\mathrm{Ru} 2-\mathrm{O} 2$ & $85.5(1)$ \\
\hline $\mathrm{O} 13-\mathrm{Ru} 1-\mathrm{O} 11$ & $179.0(1)$ & $\mathrm{O} 23-\mathrm{Ru} 2-\mathrm{O} 2$ & $95.2(1)$ \\
\hline O12-Ru1-O1 & $93.1(1)$ & $\mathrm{O} 22-\mathrm{Ru} 2-\mathrm{O} 2$ & $91.9(1)$ \\
\hline $\mathrm{O} 14-\mathrm{Ru} 1-\mathrm{O} 1$ & $87.8(1)$ & $\mathrm{O} 24-\mathrm{Ru} 2-\mathrm{Ru} 2^{\mathrm{ii}}$ & $89.59(8)$ \\
\hline $\mathrm{O} 13-\mathrm{Ru} 1-\mathrm{O} 1$ & 87.7 (1) & $\mathrm{O} 21-\mathrm{Ru} 2-\mathrm{Ru} 2^{\mathrm{ii}}$ & $89.01(8)$ \\
\hline $\mathrm{O} 11-\mathrm{Ru} 1-\mathrm{O} 1$ & $93.1(1)$ & $\mathrm{O} 23-\mathrm{Ru} 2-\mathrm{Ru} 2^{\mathrm{ii}}$ & $90.28(8)$ \\
\hline $\mathrm{O} 12-\mathrm{Ru} 1-\mathrm{Ru} 1^{\mathrm{i}}$ & $89.10(8)$ & $\mathrm{O} 22-\mathrm{Ru} 2-\mathrm{Ru} 2^{\mathrm{ii}}$ & $89.36(8)$ \\
\hline $\mathrm{O} 14-\mathrm{Ru} 1-\mathrm{Ru} 1^{\mathrm{i}}$ & $90.00(8)$ & $\mathrm{O} 2-\mathrm{Ru} 2-\mathrm{Ru}^{\mathrm{ii}}$ & $174.33(9)$ \\
\hline $\mathrm{O} 13-\mathrm{Ru} 1-\mathrm{Ru} 1^{\mathrm{i}}$ & $89.38(9)$ & $\mathrm{C} 30^{\mathrm{ii}}-\mathrm{O} 21-\mathrm{Ru} 2$ & $119.9(3)$ \\
\hline $\mathrm{O} 11-\mathrm{Ru} 1-\mathrm{Ru} 1^{\mathrm{i}}$ & $89.83(9)$ & $\mathrm{C} 40^{\mathrm{ii}}-\mathrm{O} 22-\mathrm{Ru} 2$ & $118.7(3)$ \\
\hline $\mathrm{O} 1-\mathrm{Ru} 1-\mathrm{Ru} 1^{\mathrm{i}}$ & $176.36(7)$ & $\mathrm{C} 30-\mathrm{O} 23-\mathrm{Ru} 2$ & $117.9(2)$ \\
\hline $\mathrm{C} 10-\mathrm{O} 11-\mathrm{Ru} 1$ & $118.2(2)$ & $\mathrm{O} 21^{\mathrm{ii}}-\mathrm{C} 30-\mathrm{O} 23$ & $122.9(4)$ \\
\hline $\mathrm{O} 13^{\mathrm{i}}-\mathrm{C} 10-\mathrm{O} 11$ & $123.0(3)$ & $\mathrm{O} 21^{\mathrm{ii}}-\mathrm{C} 30-\mathrm{C} 31$ & $117.7(4)$ \\
\hline $\mathrm{O} 13^{\mathrm{i}}-\mathrm{C} 10-\mathrm{C} 11$ & $114.4(8)$ & $\mathrm{C} 40-\mathrm{O} 24-\mathrm{Ru} 2$ & $119.3(3)$ \\
\hline $\mathrm{O} 11-\mathrm{C} 10-\mathrm{C} 11$ & $122.5(8)$ & $\mathrm{O} 22^{\mathrm{ii}}-\mathrm{C} 40-\mathrm{O} 24$ & $123.0(4)$ \\
\hline $\mathrm{O} 13^{\mathrm{i}}-\mathrm{C} 10-\mathrm{C} 11^{\prime}$ & $127(1)$ & $\mathrm{O} 22^{\mathrm{ii}}-\mathrm{C} 40-\mathrm{C} 41$ & $119.0(4)$ \\
\hline $\mathrm{O} 11-\mathrm{C} 10-\mathrm{C} 11^{\prime}$ & $110(1)$ & $\mathrm{O} 24-\mathrm{C} 40-\mathrm{C} 41$ & $117.9(4)$ \\
\hline $\mathrm{C} 20-\mathrm{O} 12-\mathrm{Ru} 1$ & $119.3(2)$ & $\mathrm{O} 3-\mathrm{S}-\mathrm{O} 1$ & $112.5(2)$ \\
\hline $\mathrm{O} 12-\mathrm{C} 20-\mathrm{O} 14^{\mathrm{i}}$ & $123.6(4)$ & $\mathrm{O} 3-\mathrm{S}-\mathrm{O} 2$ & $116.4(2)$ \\
\hline $\mathrm{O} 12-\mathrm{C} 20-\mathrm{C} 21$ & $118.6(4)$ & $\mathrm{O} 1-\mathrm{S}-\mathrm{O} 2$ & $108.32(18$ \\
\hline $\mathrm{O} 14^{\mathrm{i}}-\mathrm{C} 20-\mathrm{C} 21$ & $117.8(4)$ & $\mathrm{O} 3-\mathrm{S}-\mathrm{C} 50$ & $105.8(3)$ \\
\hline $\mathrm{C} 10^{\mathrm{i}}-\mathrm{O} 13-\mathrm{Ru} 1$ & $119.5(3)$ & $\mathrm{O} 1-\mathrm{S}-\mathrm{C} 50$ & $106.7(2)$ \\
\hline $\mathrm{C} 20^{\mathrm{i}}-\mathrm{O} 14-\mathrm{Ru} 1$ & $117.9(3)$ & $\mathrm{O} 2-\mathrm{S}-\mathrm{C} 50$ & $106.5(2)$ \\
\hline $\mathrm{O} 24-\mathrm{Ru} 2-\mathrm{O} 21$ & $92.3(1)$ & $\mathrm{S}-\mathrm{O} 1-\mathrm{Ru} 1$ & $129.6(2)$ \\
\hline $\mathrm{O} 24-\mathrm{Ru} 2-\mathrm{O} 23$ & $87.6(1)$ & $\mathrm{S}-\mathrm{O} 2-\mathrm{Ru} 2$ & $147.4(2)$ \\
\hline $\mathrm{O} 21-\mathrm{Ru} 2-\mathrm{O} 23$ & $179.3(1)$ & $\mathrm{C} 51-\mathrm{C} 50-\mathrm{S}$ & $113.8(4)$ \\
\hline
\end{tabular}

Symmetry codes: (i) $1-x, 1-y, 1-z$; (ii) $-x, 2-y, 1-z$. 


\section{metal-organic compounds}

\section{Data collection}

Nonius KappaCCD area-detector diffractometer

CCD scans

Absorption correction: numerical (Spek, 1990)

$T_{\min }=0.782, T_{\max }=0.965$

31736 measured reflections

\section{Refinement}

Refinement on $F^{2}$

$R\left[F^{2}>2 \sigma\left(F^{2}\right)\right]=0.049$

$w R\left(F^{2}\right)=0.155$

$S=1.11$

11539 reflections

647 parameters

$\mathrm{H}$-atom parameters constrained
11539 independent reflections 8728 reflections with $I>2 \sigma(I)$

$R_{\text {int }}=0.084$

$\theta_{\max }=27.5^{\circ}$

$h=-10 \rightarrow 10$

$k=-17 \rightarrow 17$

$l=-34 \rightarrow 30$
The C11-C19 carboxylate chain is disordered. During the refinement, the corresponding occupancies were allowed to vary so as to sum to 1.0 and the $\mathrm{C}-\mathrm{C}$ bond distances were restrained to a target value of 1.51 (1) $\AA$. Several $\mathrm{H}$ atoms were located in a Fourier difference map. However, they were positioned stereochemically and refined with a riding model. The methyl $\mathrm{H}$ atoms were treated in the refinement as rigid bodies and allowed to rotate around the corresponding $\mathrm{C}-\mathrm{C}$ bond so as to maximize the sum of the observed electron density at the three calculated $\mathrm{H}$-atom positions. As expected, all methyl groups converged to staggered conformations.

Data collection: KappaCCD Software (Nonius, 1997); cell refinement: SCALEPACK (Otwinowski \& Minor, 1997); data reduction: $D E N Z O$ and SCALEPACK; program(s) used to solve structure: SHELXS97 (Sheldrick, 1997); program(s) used to refine structure: SHELXL97 (Sheldrick, 1997); molecular graphics: PLATON (Spek, 1998); software used to prepare material for publication: Win $G X$ (Farrugia, 1999).
This work was supported by CONICET and the University of Buenos Aires (grant AX27), Argentina, and by FAPESP and the Vitae Foundation, Brazil. FDC and OEP are members of the Scientific Staff of CONICET. We thank the Cambridge Structural Database and AZ thanks the University of Buenos Aires for a student fellowship.

Supplementary data for this paper are available from the IUCr electronic archives (Reference: DA1217). Services for accessing these data are described at the back of the journal.

\section{References}

Aquino, M. A. S. (1998). Coord. Chem. Rev. 170, 141-202.

Barral, M. C., Jiménez-Aparicio, R., Priego, J. L., Royer, E. C., Urbanos, F. A. \& Amador, U. (1997). J. Chem. Soc. Dalton Trans. pp. 863-868.

Bennett, M. J., Caulton, K. G. \& Cotton, F. A. (1969). Inorg. Chem. 8, 1-6.

Bino, A., Cotton, F. A. \& Felthouse, T. R. (1979). Inorg. Chem. 18, 9, 25992604

Caplan, J. F., Murphy, C. A., Swansburg, S., Lemieux, R. P., Cameron, S. \& Aquino, M. A. S. (1999). Can. J. Chem. 76, 1520-1523.

Chaia, Z., Heinrich, B., Cukiernik, F. D. \& Guillon, D. (1999). Mol. Cryst. Liq. Cryst. 330, 213-220.

Cotton, F. A., Matusz, M. \& Zhong, B. (1988). Inorg. Chem. 27, 4368-4372. Cukiernik, F. D., Ibn-Elhaj, M., Chaia, Z. D., Marchon, J. C., Giroud-Godquin, A. M., Guillon, D., Skoulios, A. \& Maldivi, P. (1998). Chem. Mater. 10, 83 91.

Cukiernik, F. D., Luneau, D., Marchon, J. C. \& Maldivi, P. (1998). Inorg. Chem. 37, 3698-3704.

Farrugia, L. J. (1999). J. Appl. Cryst. 32, 837-838.

Nonius (1997). KappaCCD Software. Nonius BV, Delft, The Netherlands. Otwinowski, Z. \& Minor, W. (1997). Methods in Enzymology, Vol. 276,

Macromolecular Crystallography, Part A, edited by C. W. Carter \& R. M. Sweet, pp. 307-326. London: Academic Press.

Sheldrick, G. M. (1997). SHELXS97 and SHELXL97. University of Göttingen, Germany.

Spek, A. L. (1990). Acta Cryst. A46, C-34

Spek, A. L. (1998). PLATON. University of Utrecht, The Netherlands. Togano, T., Mukaida, M. \& Nomura, T. (1980). Bull. Chem. Soc. Jpn, 53, 2085 2086. 